Crop Breeding and Applied Biotechnology 13: 41-48, 2013

Brazilian Society of Plant Breeding. Printed in Brazil

\title{
ARTICLE
}

\section{Two cycles of recurrent selection in red bean breeding}

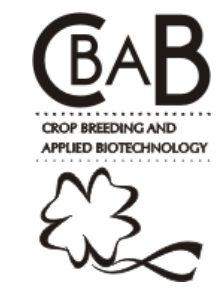

José Ângelo Nogueira de Menezes Júnior ${ }^{*}$, Laércio da Silva Rezende Júnior ${ }^{1}$, Gilmar Silvério da Rocha ${ }^{1}$, Vanessa Maria Pereira e Silva ${ }^{1}$, Alisson Campos Pereira ${ }^{1}$, Pedro Crescêncio Souza Carneiro ${ }^{1}$, Luis Alexandre Peternelli ${ }^{1}$ and José Eustáquio de Souza Carneiro ${ }^{1}$

Received 28 February 2012

Accepted 23 August 2012

\begin{abstract}
This study was carried out for the purpose of estimating genetic progress after two cycles of recurrent selection in red bean breeding and of obtaining new lines. In cycle zero, $F_{3: 5}$ and $F_{3: 6}$ families were evaluated. In cycle one, the families were extracted in generation $F_{5}$ and evaluated in generations $F_{5.6}$ and $F_{5.7}$. As the families were evaluated in different years and generations, the estimate of genetic progress was obtained by simultaneously evaluating the 30 best lines obtained at the end of each cycle in experiments conducted through three crop seasons. After two cycles of recurrent selection, genetic progress, in the mean value of the crop seasons, was 7.5\% for grain yield, $7 \%$ for grain appearance, $33.4 \%$ for resistance to rust and $13.2 \%$ for resistance to angular leaf spot. Lines of red beans were obtained with potential for being included in future Value for Cultivation and Use (VCU) testing for Minas Gerais, Brazil.
\end{abstract}

Key words: Phaseolus vulgaris, quantitative genetics, plant breeding

\section{INTRODUCTION}

The common bean crop has great variability in seed coloring. This fact leads to some types of common beans sold regionally receiving little to no attention in breeding programs. In the case of bright colored red beans, which is the most consumed type in the Zona da Mata of Minas Gerais, the Common Bean Program of the Universidade Federal de Viçosa (Federal University of Viçosa) (UFV) has striven to obtain new cultivars to meet the needs of producers (Carneiro et al. 2006).

As the demand for red beans has been ever greater and the cultivars with this type of seed are not satisfactory in regard to grain yield, disease resistance and upright plant architecture, obtaining new lines is fundamental. In this process, the use of recurrent selection has been expanded in the common bean crop, with examples in breeding of various characteristics (Singh et al. 1999, Cunha et al. 2005, Ramalho et al. 2005a, Silva et al. 2007, Arantes et al. 2010).

Recurrent selection is a dynamic method in which the best individuals or families selected in a cycle of recurrent selection are recombined in a directed, organized and predetermined manner, keeping the breeder from losing time defining which lines should be crossed, or even keeping the program from losing continuity. In other breeding methods, crosses are made between lines with desirable phenotypes with a view toward selecting individuals that gather the characteristics of interest from the different parents in only one stage. In contrast, in recurrent selection, the breeder undertakes planning to carry out various selection cycles. Thus, the favorable alleles are accumulated in stages and the breeding program is more dynamic and organized.

In recurrent selection programs, the estimate of genetic progress should be obtained periodically for the purpose of guiding the breeder in carrying out the following cycles and also to assisting the breeder in making important decisions regarding the alternatives that may increase genetic gain. To estimate genetic progress from recurrent selection, various alternatives have been used, among them, the use of common controls in evaluation of the families in the different cycles (Amaro et al. 2007, Menezes Júnior et al. 2008); the use of $\mathrm{S}_{2}$ and $\mathrm{S}_{3}$ families chosen according to greater yield (Ranalli 1996, Singh et al. 1999); comparison of $S_{1: 2}$ families simultaneously extracted in populations of various selection cycles (Silva et al. 2007); and the use of the best lines identified in the different cycles (Ramalho et al. 2005a).

In light of the above, this study was performed for the purpose of estimating genetic progress after two cycles of

\footnotetext{
${ }^{1}$ Universidade Federal de Viçosa, Departamento de Fitotecnia, 36.570-000, Viçosa, MG, Brazil. *E-mail: joseangelo@iapar.br
} 
recurrent selection in red bean breeding and of obtaining lines with a view toward composition of Value for Cultivation and Use (VCU) testing for the state of Minas Gerais, Brazil.

\section{MATERIALS AND METHODS}

The experiments were conducted in the Experimental Field of Coimbra belonging to the Plant Science Department of the Universidade Federal de Viçosa (Federal University of Viçosa) (UFV), municipality of Coimbra (lat $20^{\circ} 45^{\prime} \mathrm{S}$, long $42^{\circ} 51^{\prime} \mathrm{W}$ and alt $690 \mathrm{~m}$ asl), state of Minas Gerais. To begin the recurrent selection program, the cultivar Vermelhinho, the only one with red beans, used by farmers of the Zona da Mata in Minas Gerais, was crossed with the following cultivars and elite lines: Aporé, Pérola, IAPAR31, IAPAR81, AN9022180 and LR720982CP, with carioca-type beans (cream color with beige streaks) and AFR19521, AFR19535, AB136 and Vermelho2157, with red beans. Eighteen hybrid combinations derived from single crosses, double crosses and back crosses were generated, always involving the cultivar Vermelhinho, as described by Menezes Júnior et al. (2011).

The recurrent selection program was conducted by evaluating families for two generations and recombination of the best families for obtaining the following cycle. In cycle zero $\left(\mathrm{C}_{0}\right) \mathrm{F}_{3: 5}$ and $\mathrm{F}_{3: 6}$ families were evaluated and $\mathrm{F}_{3: 7}$ families recombined. In cycle one $\left(\mathrm{C}_{\mathrm{T}}\right)$, the families were extracted in the $\mathrm{F}_{5}$ generation and evaluated in the $\mathrm{F}_{5: 6}$ and $\mathrm{F}_{5: 7}$ generations, with the recombination being performed using $\mathrm{F}_{5: 8}$ families. Experimental details are presented in Table 1 . In each cycle, after selection of the best families for recombination, they continued being evaluated for the purpose of extraction of the lines.

In the recombination phase, for obtaining the cycle one $\left(\mathrm{C}_{\mathrm{I}}\right)$ population, as well as $17\left(\mathrm{~F}_{3: 7}\right)$ families selected in cycle zero, three new parents were included (VR-3,
VR-2 and BRS Timbó). These three lines, as well as being productive, are sources of resistance to angular leaf spot and rust, important diseases in the common bean crop. The recombination of the 20 parents $\left(17 \mathrm{~F}_{3: 7}\right.$ families and three new lines) was carried out using a circulant diallel cross in which each parent participated in two crosses.

In cycle zero, the families were evaluated only in regard to grain yield $\left(\mathrm{kg} \mathrm{ha}^{-1}\right)$. In cycle one, however, in addition to grain yield (YIELD), grain appearance (GA), plant architecture (PA) and severity of rust (RUST) were evaluated in the $\mathrm{F}_{5: 6}$ generation, and angular leaf spot (ALS) in the $\mathrm{F}_{5: 7}$ generation. Grain appearance was evaluated considering a grading scale ranging from 1 to 5 , in which 1 refers to the typical red bean with seed coat shininess, not flattened, elliptical format and average 100 seed weight from 22 to $24 \mathrm{~g}$, and 5 to the bean outside the red standard (Menezes Júnior et al. 2011). Evaluation of plant architecture was also carried out by means of a grading scale ranging from 1 to 5 in which 1 refers to the growth habit II plant, upright, with one stem and with increased height of the lowest pod, and 5 refers to the growth habit III plant, with long internodes and very prostrate growth (Collicchio et al. 1997). Severity of rust was evaluated using a six-degree grading scale (Stavely et al. 1983, adapted), with 1 being absence of visible pustules (immune) and 6 being severe disease symptoms, resulting in premature leaf drop. To evaluate the severity of angular leaf spot, a nine-degree grading scale was used, as described by Van Schoonhoven and Pastor-Corrales (1987), with 1 being plants without disease symptoms, and 9 being severe disease symptoms, resulting in premature leaf drop.

Before proceeding with data analysis, the basic presuppositions of analysis of variance were tested. The observations were submitted to analysis of variance by generation, considering all the effects of the model as random, except for the mean value, according to the following statistical

Table 1. Experimental details of evaluation of red bean families in the two cycles of recurrent selection

\begin{tabular}{|c|c|c|c|c|}
\hline Generation & \multicolumn{2}{|c|}{$\mathrm{C}_{0}$} & \multicolumn{2}{|c|}{$\mathrm{C}_{\mathrm{I}}$} \\
\hline No. of families & 243 & 243 & 380 & 160 \\
\hline Crop Year & 2002 & 2002 & 2007 & 2008 \\
\hline Crop Season & dry & winter & winter & dry \\
\hline No. of replications & 3 & 3 & 2 & 3 \\
\hline Plot size & $22 \mathrm{~m}$ rows & $22 \mathrm{~m}$ rows & $12 \mathrm{~m}$ row & $22 \mathrm{~m}$ rows \\
\hline \multirow[t]{2}{*}{ Traits evaluated } & yield & yield & yield & yield \\
\hline & - & - & grain appearance & grain appearance \\
\hline
\end{tabular}


model: $Y_{i k l}=m+p_{i}+r_{k}+b_{l(k)}+e_{i k l}$, in which $Y_{i k l}$ is the value observed in the plot that received treatment $i$ in block $l$, within replication $k ; m$ is the general mean value of the experiment; $p_{i}$ is the effect of treatment $i ; r_{k}$ is the effect of replication $k ; b_{l(k)}$ is the effect of block $l$ within replication $k ; e_{i k l}$ is the experimental error associated with observation $Y_{i k l}$, assuming that the errors are independent and normally distributed, with mean value zero and variance $\sigma^{2}$. After that, joint analysis of variance was performed using the adjusted mean values of the treatments, according to Ramalho et al. (2005b). Based on the expected mean squares, genetic variance $\left(\hat{\sigma}_{p}^{2}\right)$, phenotypic variance $\left(\hat{\sigma}_{F}^{2}\right)$, variance of the family $\mathrm{x}$ generation interaction $\left(\hat{\sigma}_{(P x G)}^{2}\right)$ and heritability in the broad sense $\left(h^{2}\right)$ were estimated.

As evaluations of the families in the two selection cycles were performed in different years and generations $\left(\mathrm{F}_{3: 5}\right.$ and $\mathrm{F}_{3: 6}$ in cycle zero and $\mathrm{F}_{5: 6}$ and $\mathrm{F}_{5: 7}$ in cycle one), the strategy used to estimate genetic progress (GP) from recurrent selection was comparison of the lines obtained at the end of each cycle. Thus, the 30 best lines of the zero cycle and the 30 best of cycle one were selected for simultaneous evaluation.

The 60 lines ( 30 from cycle $\mathrm{C}_{0}$ and 30 from cycle $\mathrm{C}_{\mathrm{I}}$ ) were evaluated together with the controls Vermelhinho and Ouro Vermelho in the winter crop season of 2008, dry season and winter season of 2009. A randomized block design was used with three replications and plots of two two-meter rows. In addition to grain yield (YIELD) in $\mathrm{kg} \mathrm{ha}^{-1}$, grain appearance (GA), plant architecture (PA) and severity of rust (RUST) and angular leaf spot (ALS) were evaluated, using the grading scale described above.

Observations were submitted to analysis of variance per environment, considering the effects of treatments and the mean value as fixed, according to the statistical model: $Y_{i l}=m+t_{i}+r_{j}+e_{i j}$ in which: $Y_{i l}$ is the value observed in the plot that received treatment $i$ within block $j ; m$ is the general mean of the experiment; $t$ is the effect of the treatment $i(i=1,2,3, \ldots, 62) ; r_{j}$ is the effect of the replication $j(j=1,2$ and 3$)$ and $e_{i j}$ is the experimental error associated with observation $Y_{i l}$, assuming that the errors are independent and normally distributed, with zero mean value and variance $\sigma^{2}$.

After that, using the mean values of the treatments, joint analysis of variance was performed for each characteristic, according to the procedure described by Ramalho et al. (2005b). The mean values of the lines were compared with the mean value of the cultivar Ouro Vermelho by the Dunnett test at $1 \%$ probability.

Genetic progress (GP) from recurrent selection was obtained using the following estimator:

$$
G P(\%)=\left[\left(\bar{X}_{C_{I}}-\bar{X}_{C_{0}}\right) / \bar{X}_{C_{0}}\right] \times 100
$$

in which: $\bar{X}_{C_{I}}$ is the mean value of the 30 lines of cycle one and $\bar{X}_{C_{I}}$ is the mean value of the 30 lines of cycle zero.

\section{RESULTS AND DISCUSSION}

The success of selection in recurrent selection programs is dependent on the existence of variability. Variability for grain yield was shown by the significant effect $(\mathrm{P}<0.05)$ of the family source of variation in the two selection cycles. In cycle one, the presence of variability in the population for grain appearance, plant architecture and reaction to rust and angular leaf spot was also shown by the significant effect $(\mathrm{P}<0.01)$ of the family source of variation (Table 2$)$.

Table 2. Summary of analyses of individual and joint (Joint) variance of grain yield ( $\mathrm{kg} \mathrm{ha}^{-1}$ ) (YIELD) in the $\mathrm{C}_{0}$ and $\mathrm{C}_{\mathrm{I}}$ cycles and of grades of grain appearance (GA), plant architecture (PA) and severity of rust (RUST) and angular leaf spot (ALS) of the $\mathrm{C}_{\mathrm{I}}$ cycle in reference to evaluation of the segregating families of the recurrent selection program, with the respective estimates of genetic variance $\left(\hat{\sigma}_{P}^{2}\right)$, phenotypic variance $\left(\hat{\sigma}_{F}^{2}\right)$, variance of the family $\mathrm{x}$ generation interaction $\left(\hat{\sigma}_{(P X G)}^{2}\right)$ and heritability in the broad sense $\left(\mathrm{h}^{2}\right)$

\begin{tabular}{|c|c|c|c|c|c|c|c|c|c|c|c|c|c|c|}
\hline \multirow{3}{*}{ Generation } & \multicolumn{3}{|c|}{ Cycle $\left(\mathrm{C}_{0}\right)$} & \multicolumn{11}{|c|}{ Cycle $\left(\mathrm{C}_{\mathrm{I}}\right)$} \\
\hline & \multicolumn{3}{|c|}{ YIELD } & \multicolumn{3}{|c|}{ YIELD } & \multicolumn{3}{|c|}{ GA } & \multicolumn{3}{|c|}{$\mathrm{PA}$} & \multirow{2}{*}{$\begin{array}{c}\text { RUST } \\
\mathbf{F}_{5: 6}\end{array}$} & \multirow{2}{*}{$\begin{array}{c}\text { ALS } \\
\mathbf{F}_{5: 7}\end{array}$} \\
\hline & $\mathbf{F}_{3: 5}$ & $\mathbf{F}_{3: 6}$ & Joint & $\mathbf{F}_{5: 6}$ & $\mathbf{F}_{5: 7}$ & Joint & $\mathbf{F}_{5: 6}$ & $\mathbf{F}_{5: 7}$ & Joint & $\mathbf{F}_{5: 6}$ & $\mathbf{F}_{5: 7}$ & Joint & & \\
\hline CV (\%) & 12.9 & 12.6 & 13.2 & 14.4 & 12.2 & 12.9 & 14.6 & 15.6 & 16.3 & 14.5 & 8.3 & 11.8 & 22.8 & 22.9 \\
\hline$\hat{\sigma}_{P}^{2}$ & 62732.4 & 236064.4 & 23214.4 & 145608.5 & 56193.1 & 26250.3 & 0.513 & 0.142 & 0.124 & 0.117 & 0.036 & 0.04 & 0.663 & 0.339 \\
\hline$\hat{\sigma}_{F}^{2}$ & 114386.5 & 254018.3 & 103708.4 & 266202.7 & 111930.5 & 91570.6 & 0.56 & 0.182 & 0.172 & 0.263 & 0.069 & 0.097 & 0.851 & 0.788 \\
\hline$\hat{\sigma}_{(P x G)}^{2}$ & - & - & 126184.1 & - & - & 45004.3 & - & - & 0.052 & - & - & 0.029 & - & - \\
\hline $\mathrm{h}^{2}$ & 54.8 & 92.9 & 22.4 & 54.7 & 50.2 & 28.7 & 91.7 & 78.2 & 71.8 & 45.3 & 52.4 & 42.6 & 77.6 & 42.8 \\
\hline $\mathrm{LI}^{2}$ & 43.9 & 91.2 & 0.1 & 44.4 & 35.4 & 2.6 & 90.1 & 71.7 & 61.5 & 32.9 & 37.8 & 21.5 & 72.6 & 25.3 \\
\hline
\end{tabular}

${ }^{1}$ Lower and upper limits of genetic variance, obtained according to Ramalho et al. (2005b); ${ }^{2}$ Lower and upper limits of heritability obtained, according to Knapp et al. (1985); $\mathrm{MS}_{\mathrm{Families}}$ - Mean square of families; CV (\%) - Coefficient of variation; * ** Significant at 5 and $1 \%$ of probability. 
Estimates of the genetic and phenotypic parameters (Table 2) also manifested the existence of variability among the families for all the traits evaluated, corroborating the results from analyses of variance. Observe that the lower limit of genetic variance in all situations was positive, indicating that genetic variance among the families must be different from zero at $95 \%$ confidence level. Estimates of heritability $\left(\mathrm{h}^{2}\right)$ also confirmed the presence of variability among the families. In all cases, the lower limit of the $\mathrm{h}^{2}$ was positive indicating that the estimates obtained at the $95 \%$ confidence level should be different from zero. It is fitting to mention that these estimates are in the broad sense; however, as dominance is not expressive in the $\mathrm{F}_{3: 5}, \mathrm{~F}_{3: 6}, \mathrm{~F}_{5: 6}$ and $\mathrm{F}_{5: 7}$ generations, it may be inferred that a large part of the variance present in the numerator of $\mathrm{h}^{2}$ must be additive (Moreto et al. 2007).

In cycle one, the contribution of variance of the family $x$ generation interaction in relation to genetic variance $\left(\hat{\sigma}_{(P x G)}^{2} / \hat{\sigma}_{P}^{2}\right)$ was expressive for plant architecture and for grain appearance (Table 2). For grain yield, the estimate of variance of the family $\mathrm{x}$ generation interaction was greater than genetic variance in the two cycles (Table
2). The genotype $x$ environment interaction has been expressive in most of the studies undertaken in the state of Minas Gerais with the common bean crop (Carneiro et al. 2002, Cunha et al. 2005, Melo et al. 2006).

As the evaluation of the families in the two cycles of recurrent selection was carried out in different years and generations $\left(\mathrm{F}_{3: 5}\right.$ and $\mathrm{F}_{3: 6}$ in cycle zero and $\mathrm{F}_{5: 6}$ and $\mathrm{F}_{5: 7}$ in cycle one), the strategy used to estimate genetic progress with recurrent selection was a comparison of the lines obtained at the end of each cycle. A significant effect of the lines was observed for all the characteristics evaluated (Table $3)$. Variation was also detected $(\mathrm{P}<0.01)$ among the lines within the groups $\left(\mathrm{C}_{0}\right.$ and $\left.\mathrm{C}_{\mathrm{T}}\right)$, except for angular leaf spot among the lines of cycle one $\left(\mathrm{C}_{\mathrm{I}}\right)$. The contrast of $\mathrm{C}_{0} \mathrm{vs} . \mathrm{C}_{\mathrm{I}}$ was not significant only for plant architecture, indicating that there was no genetic progress for this characteristic. For the other characteristics, a significant effect $(\mathrm{P}<0.01)$ was detected for the $\mathrm{C}_{0}$ vs. $\mathrm{C}_{\mathrm{I}}$ contrast.

The line $\mathrm{x}$ environment interaction was significant $(\mathrm{P}<$ 0.01 ) for all the traits (Table 3), indicating that the behavior

Table 3. Summary of joint analyses of variance of yield $\left(\mathrm{kg} \mathrm{ha}^{-1}\right)$ (YIELD) and grades of grain appearance (GA), plant architecture (PA) and severity of rust (RUST) and angular leaf spot (ALS) in reference to evaluation of red bean lines of the recurrent selection program

\begin{tabular}{|c|c|c|c|c|c|c|c|}
\hline \multirow{2}{*}{ SV } & \multirow{2}{*}{ df } & \multirow{2}{*}{$\begin{array}{c}\text { YIELD } \\
\text { MS }\end{array}$} & \multirow{2}{*}{$\begin{array}{l}\text { GA } \\
\text { MS }\end{array}$} & \multirow{2}{*}{$\begin{array}{r}\text { PA } \\
\text { MS }\end{array}$} & \multirow{2}{*}{$\begin{array}{c}\text { RUST } \\
\text { MS }\end{array}$} & \multicolumn{2}{|c|}{ ALS } \\
\hline & & & & & & df & MS \\
\hline Environments & 2 & $55652010.2^{* *}$ & $5.44^{* * *}$ & $4.48^{* *}$ & $37.13^{* *}$ & 1 & $348.56^{* *}$ \\
\hline Lines (L) & 59 & $766137.5^{* *}$ & $1.14^{* *}$ & $0.88^{* *}$ & $20.44^{* *}$ & 59 & $3.26^{* *}$ \\
\hline $\mathrm{C}_{0}$ & 29 & $806027.1^{* *}$ & $1.14^{* *}$ & $0.61^{* *}$ & $23.14^{* *}$ & 29 & $2.62^{* *}$ \\
\hline $\mathrm{C}_{0}$ vs. $\mathrm{C}_{\mathrm{I}}$ & 1 & $3909153.9^{* *}$ & $3.75^{* *}$ & 0.19 & $186.10^{* *}$ & 1 & $56.83^{* *}$ \\
\hline Controls (T) & 1 & 177607.9 & $0.68^{*}$ & 0.01 & $2.74^{*}$ & 1 & $2.09^{* *}$ \\
\hline L vs. T & 1 & $2606407.7^{* *}$ & 0.13 & 0.30 & $80.07^{* * *}$ & 1 & $23.55^{* *}$ \\
\hline Treatments $\mathrm{x}$ Environments & 122 & $370530.5^{* *}$ & $0.21^{* *}$ & $0.29^{* *}$ & $0.71^{* * *}$ & 61 & $1.27^{* *}$ \\
\hline $\mathrm{C}_{0}$ vs. $\mathrm{C}_{\mathrm{I}} \mathrm{x}$ Environments & 2 & $478350.6^{*}$ & 0.32 & $0.73^{* *}$ & 1.31 & 1 & $6.69^{* *}$ \\
\hline T x Environments & 2 & 41448.5 & 0.05 & 0.10 & 0.05 & 1 & 0.08 \\
\hline L vs. T x Environments & 2 & 211144.5 & 0.01 & 0.44 & 0.21 & 1 & 1.84 \\
\hline Mean Error & 366 & 134563.5 & 0.12 & 0.15 & 0.48 & 244 & 0.65 \\
\hline Mean & & 2366 & 2.33 & 3.90 & 2.98 & & 5.70 \\
\hline Mean $\mathrm{C}_{0}$ & & 2293 & 2.42 & 3.88 & 3.50 & & 6.06 \\
\hline Mean $\mathrm{C}_{\mathrm{I}}$ & & 2464 & 2.25 & 3.91 & 2.33 & & 5.26 \\
\hline Ouro Vermelho & & 2091 & 2.05 & 4.00 & 4.67 & & 6.67 \\
\hline Vermelhinho & & 1892 & 2.44 & 4.05 & 5.45 & & 7.50 \\
\hline
\end{tabular}

*,** Significant at 5 and $1 \%$ of probability. 
of the lines was not consistent in the different environments. For the groups of lines $\left(\mathrm{C}_{0}\right.$ and $\left.\mathrm{C}_{\mathrm{I}}\right)$ the interaction was also significant $(P<0.05)$ for all the characteristics.

In addition to estimating genetic progress with recurrent selection, these experiments were conducted to identify lines superior to the Ouro Vermelho cultivar for the purpose of composing VCU testing for Minas Gerais. The lines RVC0-1, RVC0-5 and RVC0-28 of cycle zero had lower grades than the Ouro Vermelho cultivar for severity of rust and angular leaf spot (Table 4). These lines also had grades less than or equal to the standard cultivar Ouro Vermelho for grain appear- ance and plant architecture and grades greater than or equal to Ouro Vermelho for productive performance. The $\mathrm{C}_{\mathrm{I}}$ lines that most stood out were RVCI-12, RVCI-20 and RVCI-28.

The estimate of genetic progress (GP) was obtained for each environment and for the mean value of the three evaluations (Table 5). For grain yield, the GP estimate in the winter crop season was $8.5 \%$ in 2008 and $9.6 \%$ in 2009 , whereas in the dry crop season the progress was $2.9 \%$. The difference in the estimates may be attributed to the occurrence of rust and angular leaf spot since, in the winter crop season, the climatic conditions favor the occurrence of rust, while in the dry crop

Table 4. Mean values of grain yield $\left(\mathrm{kg} \mathrm{ha}^{-1}\right)$ (YIELD) and grades of grain appearance (GA), plant architecture (PA) and severity of rust (RUST) and angular leaf spot (ALS) of red bean lines derived from two cycles of recurrent selection evaluated in three environments

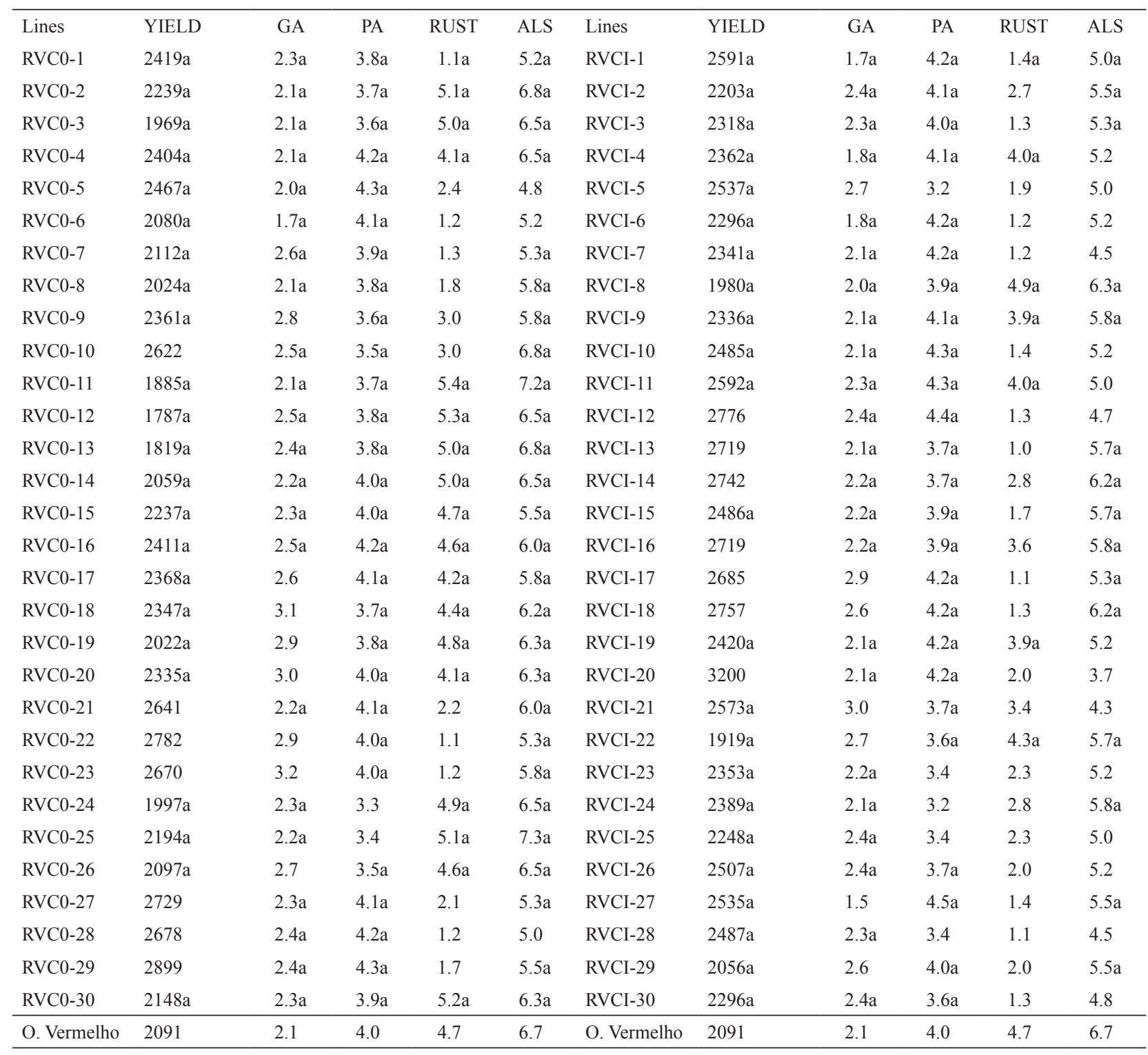

${ }^{1}$ Mean values followed by the letter a in the column do not statistically differ from the Ouro Vermelho cultivar (O. Vermelho), by the Dunnett test at $1 \%$ probability 
JAN Menezes Júnior et al.

Table 5. Estimates of genetic progress (GP\%) for grain yield (YIELD), grain appearance (GA), plant architecture (PA) and resistance to rust (RUST) and angular leaf spot (ALS), after two cycles of recurrent selection in red beans

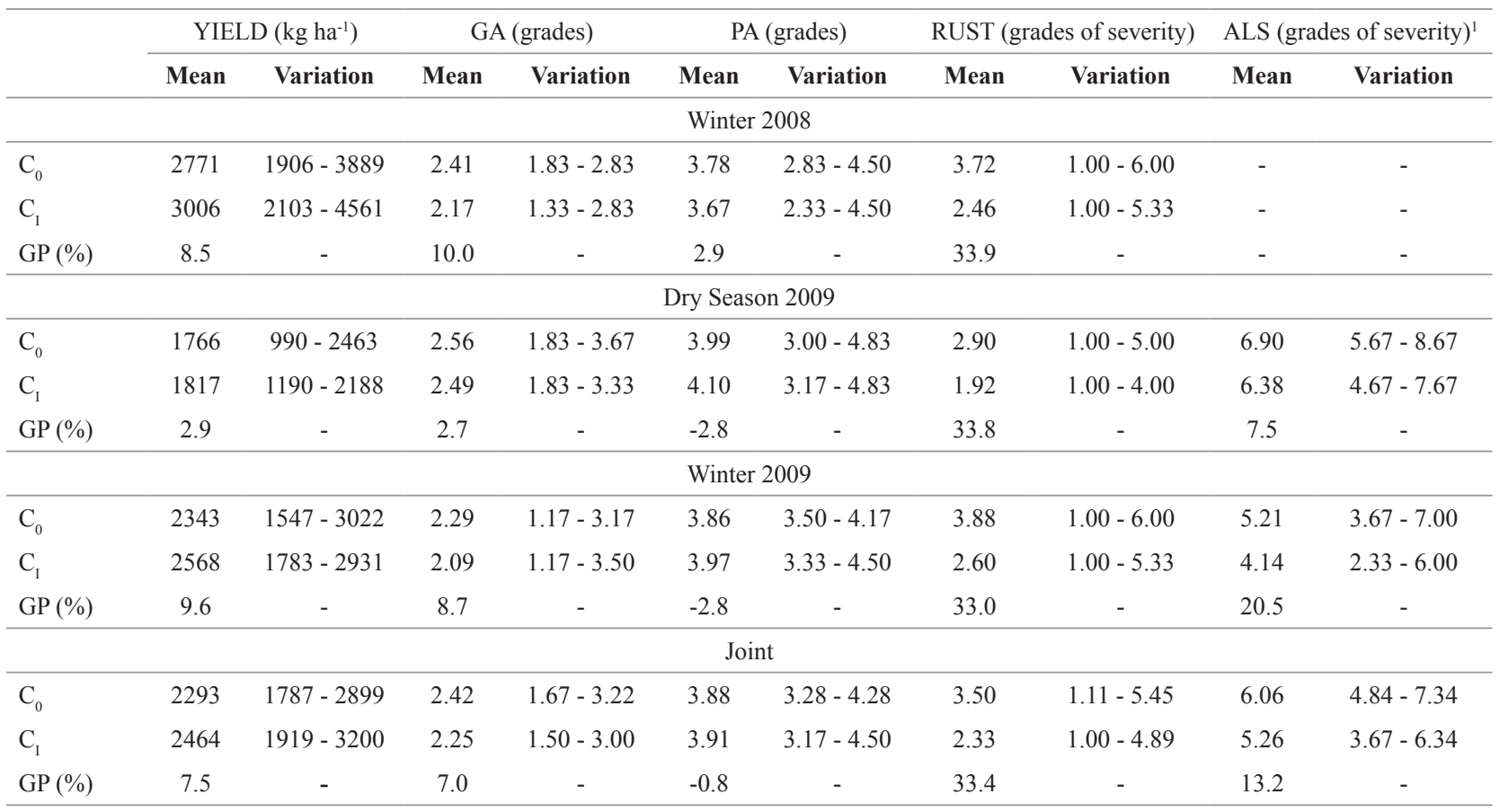

${ }^{1}$ The severity of angular leaf spot was evaluated only in the dry and winter crop seasons of 2009 .

season, the conditions are more favorable to the occurrence of angular leaf spot. As the lines of cycle one were around $33 \%$ more resistant to rust in relation to the cycle zero lines, it is possible that the greater level of resistance to rust has contributed to greater yield of these lines, leading to greater GP in the winter crop season. In contrast, in the dry crop season, the greater occurrence of angular leaf spot and the low level of resistance of the lines of the two cycles negatively affected productivity and consequently the GP in this crop season.

Considering the mean value of the three environments, the GP for grain yield was $7.5 \%$, which represents $171 \mathrm{~kg}$ $\mathrm{ha}^{-1}$ (Table 5). In the literature, estimates of genetic progress with recurrent selection in the common bean crop for grain yield range from 3.3 to 55\% (Ranalli 1996, Singh et al. 1999, Ramalho et al. 2005a, Silva et al. 2010). Evaluating the lines obtained in four cycles of recurrent selection for carioca bean breeding, Ramalho et al. (2005a) observed genetic progress of $5.7 \%$ per cycle for grain yield. In autogamous plants, comparison among GP estimates are difficult due to differences in the methodologies used in carrying out the recurrent selection programs.

The GP for grain appearance was also greater in the winter crop season (Table 5). Here, the greater occurrence of angular leaf spot may also have contributed to the lower GP estimate in the dry crop season. In this case, the disease hurt bean formation, affecting their appearance. Therefore, there was a tendency to level out the grain appearance grades of the lines of the two cycles, resulting in lower GP. Considering the three evaluations, the GP was $7 \%$. In carioca beans, estimates of genetic progress with recurrent selection for grain appearance have been reported at around 10\% (Ramalho et al. 2005a, Menezes Júnior et al. 2008).

In regard to resistance to rust, genetic progress was above $33 \%$ in the three environments and in the mean value of the evaluations (Table 5). For angular leaf spot, considering the mean value of the two environments in which this disease was evaluated, genetic progress was $13.2 \%$. It is worth emphasizing that genetic progress in this case is a result of reduction in severity of the disease, i.e., increase in resistance to the pathogen. In the literature, estimates of genetic progress for resistance to rust were not found. For angular leaf spot, Amaro et al. (2007) obtained genetic progress of $6.3 \%$ per cycle, after six cycles of phenotypic recurrent selection.

For plant architecture, it may be said that there was no genetic progress since the $\mathrm{C}_{0}$ vs. $\mathrm{C}_{\mathrm{I}}$ contrast was not significant (Table 3). This fact was already expected because in the choice of the parents used in composition of the population base, this characteristic was not taken into consideration. As the recommended red bean cultivars are unsatisfactory in regard to plant architecture, the inclusion of parents with upright stand becomes necessary in the population in the following cycles. 
It is important to emphasize that to obtain the cycle one population, three new parents were included (VR-3, VR-2 and BRS Timbó) for the purpose of improving the level of resistance to rust and angular leaf spot in the population. Thus, part of the genetic progress obtained must be attributed to the effect of these parents. The possibility of introducing new parents during the recombination phases is one of the advantages of recurrent selection (Geraldi 1997, Ramalho et al. 2001), making the process much more dynamic. This strategy was also successfully used by Ramalho et al. (2005a).

After two cycles of recurrent selection, genetic progress in the mean of the three crop seasons evaluated was $7.5 \%$ for grain yield, $7 \%$ for grain appearance, $33.4 \%$ for resistance to rust and $13.2 \%$ for resistance to angular leaf spot, proving the efficiency of recurrent selection in common bean breeding.
Although lines with good performance have been obtained, meeting the goals of the breeding program in a short period of time, the recurrent selection program must have continuity, because only by means of continued selection cycles will it be possible to accumulate a greater number of favorable alleles. Genetic variability in the population shows the possibility of continuing to obtain success in selection.

\section{ACKNOWLEDGEMENTS}

The authors thank the Brazilian National Research Council (CNPq), the Brazilian Federal Agency for Support and Evaluation of Graduate Education (CAPES) and Foundation for the Support of Research in the State of Minas Gerais (FAPEMIG) for financial support of the research activities in the Common Bean Program of the Federal University of Viçosa.

\section{Dois ciclos de seleção recorrente no melhoramento de feijão vermelho}

Resumo - Este trabalho foi realizado com os objetivos de estimar o progresso genético após dois ciclos de seleção recorrente no melhoramento de feijão vermelho e obter novas linhagens. No ciclo zero foram avaliadas famílias $F_{3: 5}$ e $F_{3: 6}$. No ciclo um as famílias foram extraídas na geração $F_{5}$ e avaliadas nas gerações $F_{5: 6}$ e $F_{5: 7}$ Como as familias foram avaliadas em anos e gerações diferentes, a estimativa do progresso genético foi obtida avaliando simultaneamente as 30 melhores linhagens obtidas no final de cada ciclo, em experimentos conduzidos por três safras. Após dois ciclos de seleção recorrente, o progresso genético, na média das safras, foi de 7,5\% para produtividade de grãos, 7\% para aspecto de grãos, 33,4\% para resistência a ferrugem e 13,2\% para resistência a mancha angular. Foram obtidas linhagens de feijão vermelho com potencial para serem incluídas em futuros ensaios de Valor de Cultivo e Uso (VCU) para Minas Gerais, Brasil.

Palavras-chave: Phaseolus vulgaris, genética quantitativa, melhoramento vegetal

\section{REFERENCES}

Amaro GB, Abreu AFB, Ramalho MAP and Silva FB (2007) Phenotypic recurrent selection in the common bean (Phaseolus vulgaris L.) with carioca-type grains for resistance to the fungi Phaeoisariopsis griseola. Genetics and Molecular Biology 30: 584-588.

Arantes LO, Abreu AFB and Ramalho MAP (2010) Eight cycles of recurrent selection for resistance to angular leaf spot in common bean. Crop Breeding and Applied Biotechnology 10: 232-237.

Carneiro JES, Ramalho MAP, Abreu AFB and Gonçalves FMA (2002) Breeding potential of single, double and multiple crosses in common bean. Crop Breeding and Applied Biotechnology 2: 515-524.

Carneiro JES, Silva LC, Paula Júnior TJ, Araujo GAA, Carneiro PCS, Giudice M.P, Menezes Júnior JAN, Ramalho MAP, Peloso MJ and Abreu AFB (2006) Ouro Vermelho: New red bean cultivar for Minas Gerais. Annual Report of the Bean Improvement Cooperative 49: 281-282.

Collicchio E, Ramalho MAP and Abreu AFB (1997) Associação entre o porte da planta do feijoeiro e o tamanho dos grãos. Pesquisa Agropecuária Brasileira 32: 297-304.

Cunha WG, Ramalho MAP and Abreu AFB (2005) Selection aiming at upright growth habit common bean with carioca type grains. Crop Breeding and Applied Biotechnology 5: 379-386.
Geraldi IO (1997) Selección recurrente en el mejoramiento de plantas. In Guimarães EP (ed.) Selección recurrente en arroz. CIAT, Cali, p.3-11.

Knapp SJ, Stroup WW and Ross WM (1985) Exact confidence intervals for heritability on a progeny mean basis. Crop Science 25: 192-194.

Melo CLP, Carneiro JES, Carneiro PCS, Cruz CD, Barros EG and Moreira MA (2006) Linhagens de feijão do cruzamento 'Ouro Negro' $x$ 'Pérola' com características agronômicas favoráveis. Pesquisa Agropecuária Brasileira 41: 1593-1598.

Menezes Júnior JAN, Carneiro JES, Silva VMP, Silva LC, Peternelli LA and Carneiro PCS (2011) Common bean breeding to improve red grain lines. Crop Breeding and Applied Biotechnology 11: 50-58.

Menezes Júnior JAN, Ramalho MAP and Abreu AFB (2008) Seleção recorrente para três caracteres do feijoeiro. Bragantia 67: 833-838.

Moreto AL, Ramalho MAP and Abreu AFB (2007) Estimação dos componentes da variância fenotípica em feijoeiro utilizando o método genealógico. Ciência e Agrotecnologia 31: 1035-1042.

Ramalho MAP, Abreu AFB and Santos JB (2005a) Genetic progress after four cycles of recurrent selection for yield and grain traits in common bean. Euphytica 144: 23-29. 
JAN Menezes Júnior et al.

Ramalho MAP, Ferreira DF and Oliveira AC (2005b) Experimentação em genética e melhoramento de plantas. Editora UFLA, Lavras, 322p.

Ramalho MAP, Abreu AFB and Santos JB (2001) Melhoramento de espécies autógamas. In Nass LL, Valois ACC, Melo IS and ValadaresInglis MC (ed.) Recursos genéticos e melhoramento de plantas. Fundação MT, Rondonópolis, p.201-230.

Ranalli P (1996) Phenotypic recurrent selection in common bean (Phaseolus vulgaris L.) based on performance of $\mathrm{S}_{2}$ progenies. Euphytica 87: 127-132.

Silva GS, Ramalho MAP, Abreu ABF and Nunes JAR (2010) Estimation of genetic progress after eight cycles of recurrent selection for common bean grain yield. Crop Breeding and Applied Biotechnology 10: 351-356.
Silva FB, Ramalho MAP and Abreu AFB (2007) Seleção recorrente fenotípica para florescimento precoce de feijoeiro "carioca". Pesquisa Agropecuária Brasileira 42: 1437-1442.

Singh SP, Terán H, Muñoz CG and Takegami JC (1999) Two cycles of recurrent selection for seed yield in common bean. Crop Science 39: $391-397$.

Stavely JR, Freytag GF, Steadman JR and Schwartz HF (1983) The 1983 bean rust workshop. Annual Report of the Bean Improvement Cooperative 26: iv-vi.

Van Schoonhoven A and Pastor-Corrales MA (1987) Standard system for the evaluation of bean germplasm. CIAT, Cali, $54 \mathrm{p}$. 